\title{
THE STUDENTS’ DIFFICULTIES FACTORS IN SPEAKING
}

\author{
Santi Adriani Putri ${ }^{1}$, Samsul Amri ${ }^{2}$ Ahmad $^{3}$ \\ English Study Program \\ Universitas Islam Indragiri ${ }^{1,2,3}$
}

\begin{abstract}
Speaking is a subject matter that must be learned by the students because it is the most important factor in the development of English language skills. However, it is more difficult than another subject because there are some difficulties experienced by students in speaking, such as low vocabulary mastery, the difficulties in pronouncing, confused in arranging words, afraid of making mistake and many another factors that cause of speaking difficulties such as teaching strategy, the curriculum, and the environment. The research purpose is to know the factors of the students' speaking difficulty. The design of the research is descriptive qualitative. The number of population as many as 157 students of eleventh-grade students of SMA Negeri 2 Tembilahan that consist of 6 classes. In taking the sample, the researcher uses a simple random sampling technique. The number of samples is 40 students or $25 \%$ of the population. The researcher uses a questionnaire as an instrument as many as 15 items and also uses an interview technique. After analyzing the data by using the descriptive qualitative method, it is known that the four factors of speaking difficulty have a positive value or more than $50 \%$. The values of these four factors were $62.5 \%$ for personal factors, $95 \%$ for teaching strategies factor, $90 \%$ for curriculum factor and $57.5 \%$ for the environmental factor. Therefore, it can be inferred that the dominant factor which causes students' difficulties in speaking is teaching strategies.
\end{abstract}

Keywords: Difficulty, Factors, Speaking

\section{INTRODUCTION}

Speaking can be defined as an activity to talk with the English language. Through speaking we can interact with the world community. The objectives of speaking are to inform, entertain, report, persuade, and convince one. In general, the purpose of speaking is to be able to simple oral communication in English. Speaking learning objectives should not be separated from the purpose of learning English. The benefits of speaking are to increase self-confidence. But speaking is the most important factor in the development of English language skills such as reading, writing and listening. For example, when learning writing or controlling various types of tenses, grammar and vocabulary election is not wrong. In listening, when the following activities or just listen to hear English, the listener can say back. 
The speaking materials English in high school is a collection of subject matter that must be learned by the students either grade X, XI and XII. In English learning, students are usually assigned to interpret the expression every day. The purpose to learn is to can speak fluently in English, especially the dialogue that often occurs every day. Following the Standards of Competence in English which is seen in senior high school English syllabus, speaking objectives is.

"Disclose the various meanings (interpersonal, ideational, textual) in a variety of oral texts interactional and monologues especially in the form of descriptive, narrative, spoof/recount, procedures, reports, news items anecdote, exposition, explanation, discussion, commentary, and reviews. "

Thus, material related to speaking at the high school level is a matter of monologue text in which the students are expected to reveal the meaning contained in each text.

In reality, speaking in English is more difficult than writing and reading. It is also shared by the researchers themselves. The most often experienced difficulties when speaking in English is because of the discrepancy between the writing and pronunciation of the word or phrase. Also, there are some difficulties experienced by students in speaking English which is seen in a study written by Afisa (2015) is as follows.

1. The student's low vocabulary mastery resulted from their limited knowledge of meaning vocabulary had led them difficulties in understanding the conversation.

2. The students had difficulties in pronouncing certain words because English words are different between pronunciation and writing.

3. The students were still confused about arranging words. Then, there were still some mistakes in their grammar.

4. The students were often afraid of speaking English because they were worried about making mistakes.

These difficulties can occur because of factors that affect. Factors can be interpreted as the reason that led to a problem. This means that any problems that arise naturally because of the factors that influence. According to KKBI online (2017) factor is a thing that contributed to the occurrence of something. In connection with the factors that cause difficulties when speaking English students, Sri Wahyuni (2014: 61) said that 
thing that causes a person difficulty in speaking using the English language is their lack of confidence.

From the researchers' point of view, almost all students have difficulty in speaking English. Therefore, researchers interested in carrying out a study on the difficulties in speaking English and the factors that influence them.

\section{LITERATURE REVIEW}

\section{Concept of Speaking}

Speaking is the intention of delivering events, ideas, thoughts, one's feelings to others in a clear, logical, purposeful and systematic use of oral language, so the intent to understand other people. Speaking is an oral language skill that is productive. In English Oxford living dictionary online, speaking is the action of conveying information or expressing one's feelings in speech. According to Flutcher (2003: 23), speaking is the verbal use of language to communicate with others.

"Speaking is a productive skill that can directly and empirically be observed, those observations are invariably colored by accuracy and effectiveness of a test-takers listening skill which is necessary compromises the reliability and validity of an oral production test (Brown, 2003: 140)."

The main purpose of speech is to communicate, so many expressed that a language is a communication tool. To effectively convey thoughts, the speaker should understand the meaning of everything that wants to communicate. He should be able to evaluate the effect of communications made to the audience and they must know the principles that underlie all situations talks, both generally and individually.

Speaking skill is the productive skill in the oral mode. Like the other skill, speaking is more complicated than it seems at first and involves more than just pronouncing words. There are five components of speaking skill that can be defined as follows: pronunciation, grammar, vocabulary, fluency, and comprehension. To be a good speaker the English learners have to master all of the components. However, besides those linguistic components above there are many factors that influence speaking ability such as motivations, behavior patterns, and likely mistakes. From that statement, it can be concluded that our motivation and also our environment are the emphasis factors in improving speaking skills. 
Speaking is not simply expressing something orally. However, students need to acquire some speaking aspects to have good speaking skills. As proposed by Brown (2001: 168), those aspects are pronunciation, fluency, vocabulary, and accuracy.

\section{Speaking in Senior High School}

Speaking in English is a skill someone to express desires and thoughts to anyone with an oral, but, speaking skills difficult to grow if not trained continuously and can be done with peers in the classroom, teachers of English, or other teachers who could speak English. The objective is to facilitate conversation skills, enrich vocabulary usage, improve order language, sayings enhance vocabulary, sentences in English, and train hearing so easily grasp the message of the speaker.

On learning in secondary education or senior high school, students are required to master the English language. English is the language of instruction for certain subjects. However, there are still some teachers who deliver the subject matter is bilingual (Indonesian and English) that aims to equalize the status of the school with an international. According to Rizka (2015: iii), English speaking is a material particularly difficult for some people. Basically, learning English is not so hard after all beginning students. Though just depends on how to learn and how it is applied in the field. Learning English speaking skills contextually should adjust to help students master English.

At the senior high school level, the material studied in each class speaking either tenth grade, eleventh grade, and twelve grades. As for the standard of competence and basic competences can be seen speaking in English syllabus SMA / MA Curriculum 2013.

Table 1 English syllabus SMA / MA Curriculum 2013

\begin{tabular}{|c|c|}
\hline Standar Kompetensi & $\begin{array}{l}\text { Berbicara } \\
\text { 10. Mengungkapkan makna dalam teks lisan fungsional } \\
\text { dan monolog pendek sederhana berbentuk recount, dan } \\
\text { narrative untuk berinteraksi dengan lingkungan sekitar }\end{array}$ \\
\hline Kompetensi Dasar & $\begin{array}{l}\text { 10.2 Mengungkapkan makna dalam monolog pendek } \\
\text { sederhana dengan menggunakan ragam bahasa lisan secara } \\
\text { akurat, lancar, dan berterima untuk berinteraksi dengan } \\
\text { lingkungan sekitar dalam teks berbentuk recount dan } \\
\text { narrative. }\end{array}$ \\
\hline
\end{tabular}




\section{Factors of Difficulties in Speaking}

According to Ur (1996:117) in Afisa (2015), many factors cause difficulty in speaking, they are as follows: inhibition, nothing to say, low or uneven participation and mother tongue. In addition, Raba'ah (2005:15) in Afisa (2015) pointed out that many factors cause difficulties in speaking English. Some of these factors are related to the learners themselves, the teaching strategies, the curriculum, and the environment. For example, many learners lack the necessary vocabulary to get their meaning across, and consequently, they cannot keep the interaction going. Inadequate strategic competence and communication competence can be another reason as well for not being able to keep the interaction going.

\section{RESEARCH METHOD}

This research was designed as survey research including direct observation of the object under study to obtain the relevant data. The method used in this research is using both qualitative and quantitative analytical research methods. In general, survey research can be divided into two, namely, cross-sectional surveys and longitudinal surveys. The cross-sectional survey is research that only requires a one-time survey course to get the data. The longitudinal survey is descriptive research that requires many times to get the data. According to Gay (2000:279), longitudinal surveys collect the data at two or more times to measure changes over time.

This research was conducted at SMA Negeri 2 Tembilahan which is located at J1. Tanjung Harapan Tembilahan, Indragiri Hilir, Riau. Moreover, the sample is representative of the population that can provide the research data. According to Riduwan (2004: 56), the sample is a part or representative of the population, named the research sample if we intend to generalize the result of the research sample. The numbers of the population of this research are 157 students. Riduwan (2004: 56) said that if the population is less than 100, it is suggested all as a research sample, but if the population is more than 100 , we can take only $20 \%-25 \%$ or $30 \%-35 \%$. In this case, the numbers of the sample in this research are as many as $25 \%$ of the population. Thus there were 40 students as the samples of this research. 
Furthermore, research instruments that are used in this research are questionnaires and interviews. The questionnaire is intended to obtain data concerning the students' difficulties in speaking. While the interview is used to collect to obtain the data concerning the factors that cause students' difficulties.

Then the researcher should analyze the data to find meaning than that meaning into the results. In general, the process of data analysis is done through data reduction, presentation or display of data and conclusions or Verification (Miles, 1992:16). Moreover, the researcher used a questionnaire as a research instrument. The scale which is used in the questionnaire is the Guttman scale. Riduwan (2004: 91) said that the Guttman scale is used if someone wants to know the clear answer, such as yes or no which the score of the answer (yes) is 1 and the score of the answer (no) is 0. Therefore, the questionnaire has been analyzed in the following way. The interval in analyzing the questionnaire bases on the formula:

$$
\mathrm{I}=\frac{R}{K}
$$

I : Interval $\quad \mathrm{R}$ : Range $\mathrm{K}$ : Category

(Riduwan, 2004: 91)

Based on the formula above, it is found that the range is the highest score - the lowest score or 1-0 $=1$. And, it was known that the categories are (yes) and (no) or category is (2). Therefore the interval is $1 / 2$ or 0.5 or $50 \%$. Therefore, the criteria of the questionnaire score have 2 types that can be seen below.

1. If the score biggest or the same with $50 \%$, the score is positive

2. If the score lowest than $50 \%$, the score is negative

\section{FINDINGS AND DISCUSSION}

\section{The Analysis of Questionnaire}

The questionnaire was formed in a Gutman-Scale questionnaire where there are 2 optional answers to each statement. Both options are (Yes) and (No). For the answer (Yes) is assigned a value (1) and for the answer (No) is assigned a value (0). All questions required respondents to provide the answers based on their perspective opinions on the difficulties in English speaking. The questionnaire consists of four indicators where each indicator there are several questions. They are learners 
themselves, teaching strategy, curriculum, and environment. Therefore, the researcher has analyzed these four indicators in the explanation below.

\section{a. Learners Themselves}

Learners themselves are the main factor causing a person to feel difficult or not when speaking English because with personal ability someone can speak English. This includes vocabulary mastery, word pronunciation skills, grammatical mastery, and selfesteem. In the first indicator, there are 7 questions. The data obtained through a questionnaire about the first indicator which is the answer of the respondents can be seen in the table below.

Table 2 The Data of Learner Themselves Factor

\begin{tabular}{|c|c|c|c|}
\hline \multicolumn{4}{|c|}{ Learner Themselves Factor } \\
\hline Criteria & Score & Mean Score & Percentages \\
\hline Yes & 25 & 0.625 & $62.5 \%$ \\
\hline No & - & - & - \\
\hline
\end{tabular}

Based on the data which has been obtained from the research respondents as much as 40 respondents, this indicator lies in the higher area than half. The score was 0.625.

\section{b. The Teaching Strategy}

The second indicator that can cause difficult or not speak English is a teaching strategy, which is the strategy used by the English teacher to learn English especially about speaking. In other words, an English teacher must be smart in dealing with situations or circumstances where students can feel comfortable while studying. In this indicator, there are 3 questions. The data obtained through questionnaire research on this indicator can be seen in the table below.

Table 3 the Data of Teaching Strategies

\begin{tabular}{|c|c|c|c|}
\hline \multicolumn{4}{|c|}{ Teaching Strategies } \\
\hline Criteria & Score & Mean Score & Percentages \\
\hline Yes & 36.67 & 0.95 & $95 \%$ \\
\hline No & - & - & - \\
\hline
\end{tabular}

Based on the data which has been obtained from the respondents of the research as much as 40 respondents, the teaching strategies lie in the area that almost close to the perfect that is at 0.95 . 


\section{c. The Curriculum}

This indicator is a common factor that always faced by the students in learning English because, at the level of junior high school, English material is usually studied more than other subjects. Therefore, students should be more mastering the English language especially speaking material than other subjects. In this indicator, there are 2 questions. The data that has been obtained through can be seen in the table below.

Table 4 The Data of Curriculum

\begin{tabular}{|c|c|c|c|}
\hline \multicolumn{4}{|c|}{ Curriculum Factor } \\
\hline Criteria & Score & Mean Score & Percentages \\
\hline Yes & 36 & 0.9 & $90 \%$ \\
\hline No & - & - & - \\
\hline
\end{tabular}

Based on these data, the curriculum lies in the area close to the perfect. that is at 0.9 .

\section{d. The Environment}

The final indicator may also be referred to as an external factor in which their surroundings affect the student's speaking ability. These environments include the school environment including friends communicate and outside the school environment such as home or playground. If the environment offers a form of communication using the English language, it is better for the learners' speaking ability. In this indicator, there are 3 questions. The data that has been obtained through the questionnaire can be seen in the table below.

\section{Table 5 The Data of Environment Factor}

\begin{tabular}{|c|c|c|c|}
\hline \multicolumn{4}{|c|}{ Environment Factor } \\
\hline Criteria & Score & Mean Score & Percentages \\
\hline Yes & 23 & 0.575 & $57.5 \%$ \\
\hline No & - & - & - \\
\hline
\end{tabular}

The table above showed that the environment has a value that lies in the middle area at 0.575 .

Based on the results of research that the researcher has done in SMA Negeri 2 Tembilahan, it can be seen that the factors that cause the difficulty of speaking English include the student's factor (learners themselves), the factor of teaching strategies, the curriculum factor and the environmental factor. Based on a questionnaire that has been distributed to the students of SMA Negeri 2 Tembilahan, it is known that the four factors have positive value or more than $50 \%$ of students answer the questionnaire with 
a positive answer. The values of these four factors were $62.5 \%$ for personal factors, 95\% for teaching strategies, $90 \%$ for curriculum factors and $57.5 \%$ for environmental factors.

\section{The Analysis of Interview}

After researching by spreading the questionnaires to the respondents of the research which the students of the eleventh grade of SMA Negeri 2 Tembilahan were 40 respondents, then the result of the questionnaire analysis was used as the guideline in preparing the second instrument in the form of an interview. The interview has been done on February $26^{\text {th }}-27^{\text {th }} 2018$. The resources of the interview in this research are one of the English teachers of SMA Negeri 2 Tembilahan named Nurpanca Berlian, S. Pd and one of the eleventh grade of SMA Negeri 2 Tembilahan named Muhammad Affandi.

Based on the results of the questionnaire which has been done, it was known that the factors that cause the difficulty of speaking English include the student's factor (learners themselves), the factor of teaching strategies, the curriculum factor and the environmental factor. The four factors equally have a positive value that is greater than or equal to 0.5 in the sense of having a percentage greater than $50 \%$. This means that the four factors are the factors that cause the difficulty of speaking English.

Therefore, the interview which has been done by the researcher is aimed to find out the reason why these four factors can be the cause of the difficulty of speaking English. Here are the results of interviews conducted on English teachers and students of SMA Negeri 2 Tembilahan.

\section{a. Informant: English Teacher of SMA Negeri 2 Tembilahan}

\begin{tabular}{|c|c|c|c|}
\hline & The Questions & The Responses & Conclusions \\
\hline 1 & $\begin{array}{l}\text { From the results of research } \\
\text { by using a questionnaire that I } \\
\text { have done in the eleventh- } \\
\text { grade students of SMA Negeri } \\
2 \text { Tembilahan, it is known that } \\
\text { the factor of students' ability } \\
\text { in mastering vocabulary, } \\
\text { grammar and pronunciation is } \\
\text { the factors that have an } \\
\text { influence on difficult or not in } \\
\text { speaking English. Also, the } \\
\text { feeling of worry will make } \\
\text { mistakes when speaking }\end{array}$ & $\begin{array}{l}\text { That's because vocabulary, } \\
\text { grammar, and pronunciation are } \\
\text { important elements in English. If a } \\
\text { person's ability to master these } \\
\text { three elements has been good, then } \\
\text { their language skills will be good. } \\
\text { This is what I think is why the } \\
\text { mastery of vocabulary, grammar } \\
\text { and pronunciation is the factor that } \\
\text { influences whether or not it is } \\
\text { difficult to speak English. In } \\
\text { addition, I think a person's } \\
\text { mentality also affects the difficult }\end{array}$ & $\begin{array}{l}\text { The students' } \\
\text { ability in mastering } \\
\text { vocabulary, } \\
\text { grammar, } \\
\text { pronunciation, and } \\
\text { confidence is the } \\
\text { factor that can } \\
\text { affect the difficulty } \\
\text { or not speak } \\
\text { English. }\end{array}$ \\
\hline
\end{tabular}




\begin{tabular}{|c|c|c|c|}
\hline & $\begin{array}{l}\text { English is also one thing that } \\
\text { influences the difficult or not } \\
\text { to speak English. It was } \\
\text { proved by the data that more } \\
\text { than } 50 \% \text { of students think so. } \\
\text { Based on the data, what do } \\
\text { you think? Why is that? }\end{array}$ & $\begin{array}{l}\text { or not speak English. If someone } \\
\text { has a sense of confidence then his } \\
\text { ability to speak English will be } \\
\text { good. But many things that make } \\
\text { students less confident when } \\
\text { speaking English, such as fear of } \\
\text { mispronunciation, fear of using } \\
\text { grammar and others. But it can be } \\
\text { overcome by way of more } \\
\text { vocabulary, grammar and has a } \\
\text { good pronunciation to reduce the } \\
\text { feeling of lack of confidence. }\end{array}$ & \\
\hline 2 & $\begin{array}{l}\text { From the results of research, it } \\
\text { is known that the teaching } \\
\text { strategy is a factor that has an } \\
\text { influence on the difficult or } \\
\text { not speak English. In this case, } \\
\text { the teaching strategy means is } \\
\text { the methods that you used } \\
\text { when teaching English about } \\
\text { speaking. The results showed } \\
\text { that more than 50\% of the } \\
\text { students think that the method } \\
\text { which you use has been good. } \\
\text { Why do you think teaching } \\
\text { strategies or teaching methods } \\
\text { are the factors that make it } \\
\text { difficult or not to speak } \\
\text { English? }\end{array}$ & $\begin{array}{l}\text { Because the method of learning } \\
\text { which is used by the teachers when } \\
\text { teaching has a huge impact on the } \\
\text { success of lesson, the method which } \\
\text { is used should be under the needs of } \\
\text { students, it is mean that a teacher } \\
\text { must be able to understand the } \\
\text { condition of students to provide a } \\
\text { comfortable form of teaching. This } \\
\text { applies to all subjects especially } \\
\text { language lessons. } \\
\text { The point is if we talk about } \\
\text { speaking, I think the method is the } \\
\text { main factor of student's success in } \\
\text { sharpening speech ability itself. }\end{array}$ & $\begin{array}{l}\text { The teaching } \\
\text { strategy is a factor } \\
\text { that can affect the } \\
\text { difficulty or not } \\
\text { speak English. }\end{array}$ \\
\hline 3 & $\begin{array}{l}\text { From the results of research, it } \\
\text { is known that the English } \\
\text { language curriculum is a } \\
\text { factor that also has an } \\
\text { influence on the difficult or } \\
\text { not speak English. This is } \\
\text { evidenced by the data that } \\
\text { more than 50\% of students } \\
\text { think that English material } \\
\text { given in school can improve } \\
\text { their speaking ability. Why do } \\
\text { you think English material } \\
\text { that was given in the school } \\
\text { can improve speaking skills? } \\
\text { It is not the time of study } \\
\text { which is contained in the } \\
\text { English curriculum is very } \\
\text { little. }\end{array}$ & $\begin{array}{l}\text { Because learning English especially } \\
\text { about speaking is not absolute with } \\
\text { the amount of time that was given } \\
\text { but how the effectiveness and } \\
\text { efficiency of learning itself. This } \\
\text { means that although much time is } \\
\text { given on English material but the } \\
\text { time is not used properly, then the } \\
\text { result will not be satisfactory but } \\
\text { although little time is given on } \\
\text { English material the time is used } \\
\text { effectively and efficiently then the } \\
\text { result will be more satisfactory. } \\
\text { That is why even though the time } \\
\text { on the English lesson curriculum is } \\
\text { less but the students feel the time is } \\
\text { enough to improve their speaking } \\
\text { ability. }\end{array}$ & $\begin{array}{l}\text { The Curriculum is a } \\
\text { factor that can } \\
\text { affect the difficulty } \\
\text { or not speak } \\
\text { English. }\end{array}$ \\
\hline 4 & $\begin{array}{l}\text { From the results of the } \\
\text { research, it is known that the } \\
\text { environment either school } \\
\text { environment or outside school } \\
\text { is a factor that also has an } \\
\text { influence on the difficult or } \\
\text { not speak English. This is } \\
\text { evidenced by the data that } \\
\text { more than 50\% of students }\end{array}$ & $\begin{array}{l}\text { Because the environment is their } \\
\text { arena in exploring their ability to } \\
\text { speak either school environment or } \\
\text { environment outside the school. } \\
\text { That is, if their environment offers } \\
\text { a form of communication in } \\
\text { English, then their English skills } \\
\text { will be good but if their } \\
\text { environment offers a form of }\end{array}$ & $\begin{array}{l}\text { The environment is } \\
\text { a factor that can } \\
\text { affect the difficulty } \\
\text { or not speak } \\
\text { English. }\end{array}$ \\
\hline
\end{tabular}




\begin{tabular}{|l|l|l|l|}
\hline $\begin{array}{l}\text { Whink that so. } \\
\text { environment can have an } \\
\text { impact on students' ability to } \\
\text { speak English? }\end{array}$ & $\begin{array}{l}\text { communication in the other } \\
\text { language or mother tongue, then } \\
\text { their English skills will be less. }\end{array}$ & \\
\hline
\end{tabular}

Based on the results of interviews that have been done as seen in the script above, it was concluded that the cause of the four indicators is a factor of difficulty speaking English because these four indicators are important elements that must be mastered by learners.

\section{c. Informant: the Student of SMA Negeri 2 Tembilahan}

The Result of Interview with Students (Muhammad Affandi)

\begin{tabular}{|c|c|c|c|}
\hline No & The Question & The Response & Conclusion \\
\hline 1 & $\begin{array}{l}\text { Do you think English is a } \\
\text { difficult subject? }\end{array}$ & $\begin{array}{l}\text { There is difficult and easy, difficult } \\
\text { when learning about speaking } \\
\text { because it is difficult to say English } \\
\text { words that are not following the } \\
\text { spelling. Ease while learning tenses } \\
\text { because of tenses easier. }\end{array}$ & - \\
\hline 2 & $\begin{array}{l}\text { According to you between the } \\
\text { ability grammar mastery, } \\
\text { vocabulary and pronunciation } \\
\text { have a relationship with } \\
\text { speaking? if any relation, how } \\
\text { and explain! }\end{array}$ & $\begin{array}{l}\text { Yes, any relation. } \\
\text { When someone speaks English, he } \\
\text { needs vocabulary mastery to say the } \\
\text { right words, he requires the ability } \\
\text { to use good grammar so that the } \\
\text { words have an arrangement and he } \\
\text { requires good pronunciation to } \\
\text { make the sentences easy to } \\
\text { understand. }\end{array}$ & - \\
\hline 3 & $\begin{array}{l}\text { What do you think about } \\
\text { concerns when speaking, such } \\
\text { as worrying about wrong, } \\
\text { nervous and others? }\end{array}$ & $\begin{array}{l}\text { Not everyone is afraid when } \\
\text { speaking English, some people are } \\
\text { not afraid when speaking English } \\
\text { even if wrong. People who are } \\
\text { afraid are usually shy even though } \\
\text { he is clever. }\end{array}$ & - \\
\hline 4 & $\begin{array}{l}\text { Do you think there is a way to } \\
\text { improve speaking ability? for } \\
\text { example by learning method. }\end{array}$ & $\begin{array}{l}\text { In my opinion, using any method } \\
\text { will still be difficult to speak } \\
\text { English. Unless we can live in } \\
\text { America because people there } \\
\text { communicate by using English. }\end{array}$ & \\
\hline 5 & $\begin{array}{l}\text { Do you think about living in } \\
\text { America where the people } \\
\text { there communicate by using } \\
\text { English then you can speak } \\
\text { English? }\end{array}$ & $\begin{array}{l}\text { Not really. } \\
\text { But at least, because often hear and } \\
\text { mingle with the people there, } \\
\text { automatically we will be able to } \\
\text { speak English although not fluent. }\end{array}$ & - \\
\hline
\end{tabular}


The Result of Interview with Students (Rusmar Hadi)

\begin{tabular}{|c|c|c|c|}
\hline No & The Questions & The Responses & Conclusion \\
\hline 1 & $\begin{array}{l}\text { Do you think English is a } \\
\text { difficult subject? }\end{array}$ & $\begin{array}{l}\text { Yes, I think English is very difficult } \\
\text { because I do not like English. }\end{array}$ & - \\
\hline 2 & $\begin{array}{l}\text { According to you, whether } \\
\text { there is a relationship between } \\
\text { the ability of grammar } \\
\text { mastery, vocabulary and } \\
\text { pronunciation with speaking? } \\
\text { if any relationship, how and } \\
\text { explain! }\end{array}$ & $\begin{array}{l}\text { Of course, there are relationships. } \\
\text { Because grammar, vocabulary, and } \\
\text { pronunciation are important } \\
\text { elements when someone speaks. } \\
\text { Including when speaking English. }\end{array}$ & - \\
\hline 3 & $\begin{array}{l}\text { What do you think about } \\
\text { concerns when speaking, such } \\
\text { as worrying about wrong, } \\
\text { nervous and others? }\end{array}$ & $\begin{array}{l}\text { I do not know. But I always } \\
\text { nervous when speaking English. }\end{array}$ & - \\
\hline 4 & $\begin{array}{l}\text { Do you think there is a way to } \\
\text { improve speaking ability? for } \\
\text { example by learning method. }\end{array}$ & $\begin{array}{l}\text { I think to improve speaking ability } \\
\text { we must speak English every day, } \\
\text { everywhere and every time. But I } \\
\text { do not know about the method to } \\
\text { improve speaking ability. }\end{array}$ & \\
\hline
\end{tabular}

\section{The Result of Interview with Students (Ananda Maulidin)}

\begin{tabular}{|c|l|l|c|}
\hline No & \multicolumn{1}{|c|}{ The Questions } & \multicolumn{1}{|c|}{ The Responses } & Conclusion \\
\hline 1 & $\begin{array}{l}\text { Do you think English is a } \\
\text { difficult subject? }\end{array}$ & $\begin{array}{l}\text { Yes, I think English is a very } \\
\text { difficult subject because English } \\
\text { is like mathematics which needs a } \\
\text { formula such as tenses. }\end{array}$ & - \\
\hline 2 & $\begin{array}{l}\text { According to you, whether there } \\
\text { is a relationship between the } \\
\text { ability of grammar mastery, } \\
\text { vocabulary and pronunciation } \\
\text { with speaking? if any } \\
\text { relationship, how and explain! }\end{array}$ & $\begin{array}{l}\text { Of course, there are relationships. } \\
\text { Because without grammar, } \\
\text { someone cannot speak English. }\end{array}$ & - \\
\hline 3 & $\begin{array}{l}\text { What do you think about } \\
\text { concerns when speaking, such } \\
\text { as worrying about wrong, } \\
\text { nervous and others? }\end{array}$ & $\begin{array}{l}\text { It is natural, I think when students } \\
\text { speak English in front of the class } \\
\text { they were worrying about the } \\
\text { mistake. }\end{array}$ \\
\hline 4 & $\begin{array}{l}\text { Do you think there is a way to } \\
\text { improve speaking ability? for } \\
\text { example by learning method. }\end{array}$ & $\begin{array}{l}\text { I think to improve speaking } \\
\text { ability we must speak English in } \\
\text { daily life, }\end{array}$ & \\
\hline
\end{tabular}

Based on the results of the interview which has been done on three of eleventhgrade students of SMA Negeri 2 Tembilahan, it is concluded that the English language subjects are difficult compared to other subjects, especially the subject of speaking. That's because more students are less vocabulary, grammar and not fluent in pronouncing words or sentences in English so they will have difficulty speaking English 
though by any means. Besides, it is also concluded that the environment can be the best means if someone wants to speak good English.

Based on the result of the data presented above, the researcher has found the purposes of the research that are:

1. Factors that cause the difficulty of speaking English among others the personal factor of the students themselves, the teaching strategy factor, curriculum factor, and environmental factor. Based on a questionnaire distributed to students of SMA Negeri 2 Tembilahan, it is known that the four factors have positive value or more than $50 \%$ of students answer the questionnaire with a positive answer. The values of these four factors were $62.5 \%$ for personal factors, $95 \%$ for teaching strategies, $90 \%$ for curriculum factors and $57.5 \%$ for environmental factors.

2. English subjects are difficult subjects compared to other subjects, especially the subject of speaking. That's because more students are less vocabulary, grammar and not fluent in pronouncing words or sentences in English so they will have difficulty speaking English though in anyways. In addition, it is also concluded that the environment can be the best means if someone wants to speak good English.

\section{CONCLUSION}

The speaking lessons that are applied in the school certainly have a purpose. The purpose of speaking is to tell, entertain, report, persuade, and convince someone. However, many say that learning to speak is very difficult. Based on the results of the research by using questionnaires and interviews which have been described previously. The result of the research proved that four factors caused the difficulty to speak English. They are the student's own personal factors (learners themselves), the factor of teaching strategies, the curriculum factor and the environmental factor. Based on a questionnaire that has been distributed to the students of SMA Negeri 2 Tembilahan, it is known that the four factors have positive value or more than $50 \%$ of students answer the questionnaire with a positive answer. The values of these four factors were $62.5 \%$ for personal factors, $95 \%$ for teaching strategies, $90 \%$ for curriculum factors and $57.5 \%$ for environmental factors. Therefore, it can be inferred that the dominant factor which causes students' difficulties in speaking is teaching strategies. 


\section{REFERENCES}

Afisa, Sheila Yolanda Pradya. 2015. The Students' Difficulties In Speaking at the Tenth Grade of SMA Negeri 1 Sine in 2014/2015 Academic Year. Surakarta: Muhammadiyah University of Surakarta

Arikunto, Suharsimi. 2010. Prosedur Penelitian: Suatu Pendekatan Praktek. Jakarta: Rineke Cipta.

Brown, Anne. 2003. Collaborative Action Research for English Language Teachers. Cambridge: Cambridge University Press.

Brown, H. Douglas. 2000. Principles of Language Learning and Teaching. London: Longman.

Depdiknas. 2013. Kurikulum 2013 SMA/MA: Silabus Mata Pelajaran Bahasa Inggris. Jakarta: Depdiknas

Dianingpadmi.wordpress.com. 2007. Students' Difficulties in Speaking English and How to Solve it. Obtained in April 2018. https://dianingpadmi.wordpress.com/eedduuccaattiioonn/students\%e2\%80\%99difficulties-in-speaking-english-and-how-to-solve-it/

English oxford living dictionary. 2018. https://en.oxforddictionaries.com. obtained on march $1^{\text {th }} 2018$.

Flutcher, Glenn. 2003. Testing Second Language Speaking. Grear Britain: Pearson Education.

Gay, L.R. 2000. Education Research: Competencies for Analysis and Application. Columbus: Mercill Publishing Company.

Grimes, A David, at al. 2002. Descriptive Studies: What They Can and Can't Do. The Lancet $\bullet \operatorname{Vol} 359 \bullet$ January 12, 2002, • http://www.thelancet.com/

Harris, T., \& Hodges, R. 1995. The literacy Dictionary. Newark, DE: International Reading Association.

Longman Dictionary of Language Teaching and Applied Linguistics. 2000

Manser, Martin H. 1995. Oxford Learner's Pocket Dictionary. New York: University Press.

Margono, S. 1996. Metodologi Penelitian Pendidikan. Semarang: Rineka Cipta.

Miles, Matthew B. et al 1992. Analisis Data Qualitative. Jakarta: UI-Press.

Nirmawati, Lia Amalia. 2015. Improving Students' Speaking Skills through Speaking Board Games of Grade VIII of SMPN 13 Yogyakarta in the Academic Year of 2013/201. Yogyakarta: Faculty of Languages and Arts Yogyakarta State University.

Pusat Bahasa. 2017. Kamus Besar Bahasa Indonesia Online. https:// kamusbahasaindonesia. org/ obtained on march $1^{\text {th }} 2018$. 
Raharjo, Setyo Budi. 2015. A Study on Students' Problem in Learning English Speaking at SMA Islam Batu. Malang: University of Muhammadiyah Malang.

Riduwan. 2004. Belajar Mudah Penelitian. Bandung: Alfabeta.

Sukardi. 2003. Metodologi Penelitian Pendidikan. Yogyakarta: Bumi Aksara

Wahyuni, Sri. 2014. Hubungan Antara Kepercayaan Diri Dengan Kecemasan Berbicara di Depan Umum Pada Mahasiswa Psikologi. eJournal Psikologi, 2014,2(1): 50-64. ISSN 0000-0000, ejournal.psikologi.fisip-unmul.ac.id 